\title{
BADANIA GEOGRAFICZNE WOBEC WYZWAŃ INTERDYSCYPLINARNOŚCI STUDIÓW NAD ROZWOJEM
}

\begin{abstract}
Zarys treści Artykuł stanowi krótki przegląd koncepcji badań geograficznych nad krajami rozwijającymi się. Autorka analizuje ewolucję podejścia do kwestii rozwoju w badaniach geograficznych - od geografii krajów rozwijających się do geograficznych badań nad rozwojem i zastanawia się, jakie obecnie jest miejsce geografii rozwoju w polskich analizach na temat globalnego Południa. Wskazuje również na powiązanie podejść geograficznych z innymi w ramach nauk społecznych. Nawiązuje w tym do interdyscyplinarności analiz rozwoju i niedorozwoju w krajach globalnego Południa.
\end{abstract}

Słowa kluczowe Geografia krajów rozwijających się, geografia rozwoju, studia nad rozwojem, globalne Południe.

\section{Wprowadzenie}

Truizmem jest dzisiaj stwierdzenie, że najbardziej uderzającą cechą zagospodarowania przestrzeni i tym samym geografii gospodarczej świata jest nierównomierne rozmieszczenie wszelkiej działalności stanowiącej podstawę rozwoju miejsca, regionu, kontynentu itd. Od wielu też lat ekonomista Jeffrey Sachs głosi pogląd, że to geografia jest przyczyną nierównomiernego rozwoju świata, dysproporcji w poziomie rozwoju między krajami i regionami, biedy i niedorozwoju na świecie (Sachs 2006). Oczywiście ma tu na myśli cech położenia geograficznego i warunków środowiska naturalnego danego miejsca. Podobnie R. Hausmann (2001) uważa, że niedorozwój jest przypadkiem ,złej szerokości geograficznej". Inni autorzy postrzegają różnice $\mathrm{w}$ dochodach regionów i w poziomie zagospodarowania regionów w nieodpowiednich ich zdaniem warunkach klimatycznych (niewłaściwych dla intensywnej gospodarki), ubogich glebach, niskiej produktywności rolnictwa, w chorobach, katastrofach naturalnych etc. Co sprawia, że sprawcy sytuacji kryzysowej „współistnieją często obok siebie napędzając zamknięty krąg ubóstwa i zacofania" (Watts 2003: 65). Podając za przykład 
zróżnicowanie rozwoju w Afryce, D. Landes (1999) twierdzi, że bieda jest wprawdzie spowodowana głównie ,złą geografią" i niewystarczająco rozwiniętą infrastrukturą, jednak również istotną przyczyną niedorozwoju jest jego zdaniem „toksyczna” kultura. Rozumie przez nią dominację relacji zachowawczych i wstecznych powszechnych w społeczeństwach afrykańskich, które hamują rozwój (ibid.).

Postępowi autorzy krytykują wypowiedzi przytoczone powyżej i twierdzą, że zamiast wnosić nowe pomysły i tezy do dyskusji o przyczynach niedorozwoju „cofają ją do czasów wiktoriańskich” (Watts 2003: 66). Opierają się one bowiem na Orientalizmie, który konsekwentnie ogranicza w swojej płaszczyźnie koncepcyjnej te cechy i charakterystyki regionu, które mogłyby świadczyć o potencjale wzrostu i opiera swoją wizję o braki i niedobory, dla pokonania których należy wprowadzić rozwiązania zewnętrzne (Andreasson 2005). Jednym z postulatów J. Sachsa (2006) jest przeniesienie wzorców przynoszących wzrost z gospodarek rozwiniętych do krajów rozwijających się, aby „mogły one wspinać się po drabinie rozwoju" (Sachs 2006). G. Mohan i M. Power (2009) sprzeciwiają się takiemu podejściu i twierdzą, że stosunki imperialne w polityce i relacjach międzynarodowych dalej sprzyjają utrzymywaniu się podziałów i nierównych relacji między jednostkami w przestrzeni gospodarczej i ekonomicznej. Twierdzą, że właśnie relacje przestrzenne o różnym charakterze i zasięgu, zawsze charakteryzujące się brakiem równości, proporcji i homogeniczności, stanowią przedmiot badań geografii rozwoju.

\section{Od geografii krajów rozwijających się do geograficznych badań nad rozwojem}

Geograficzne badania nad rozwojem stanowią propozycję integracji tematyki badawczej podejmowanej zarówno przez geografię fizyczną, jak i społeczno-ekonomiczną. Ich celem jest analiza procesów społecznych i ekonomicznych przez pryzmat warunków przyrodniczych i ich osadzenie w konkretnej przestrzeni. Takie założenie sprawia, że obiektem badań są relacje i formy przestrzenne zjawisk rozwoju i niedorozwoju.

Koncepcja geograficznych badań nad rozwojem została wprowadzona do geografii przez Jürgena Blenck'a w 1979 roku (Bohle 2007). W centrum geograficznych badań nad rozwojem Blenck stawia społeczeństwo, które zajmując określoną przestrzeń o określonych warunkach środowiska przyrodniczego tworzy sieć relacji, które albo prowadzą do rozwoju albo proces ten hamują. Blenck postulował więc (już w latach 70. XX w.), żeby geografia rozwoju badała procesy rozwoju i niedorozwoju konkretnych fragmentów przestrzeni geograficznej, a nie krajów rozwijających się, jak to czyniła wcześniej (za: Bohle 2007). Tym samym nastąpiła zmiana paradygmatu badań geograficznych od stricte przestrzennych 
analiz zróżnicowań zjawisk i procesów do analiz społeczno-kulturowych przyczyn niedorozwoju i zróżnicowania poziomu życia. Geografia zaczęła stosować do wyjaśniania przestrzennych aspektów rozwoju teorie i koncepcje zapożyczone z nauk społecznych i ekonomicznych. Wyłoniła się konieczność interdyscyplinarnych badań nad rozwojem skierowanym na analizy micro-regionalne (na poziomie lokalnych społeczności i grup etnicznych). Jednocześnie włączenie się geografii do dyskusji na temat globalizacji - jej uwarunkowań i skutków środowiskowych, społecznych, ekonomicznych, kulturowych i politycznych dało impuls dla dyskusji o szerszym zasięgu przestrzennym, na poziomie wielkich regionów geograficznych i skali globalnej.

Wobec nowych wyzwań i konieczności analiz na poziomach globalnym-lokalnym, od początku XXI wieku pojawiło się wiele pytań z zakresu przedmiotu badań geograficznych badań nad rozwojem, jak też metodologii tych badań. Otwartymi kwestiami pozostały kwestie definicji rozwoju i niedorozwoju, pochodzące głównie z nauk ekonomicznych i społecznych. W geografii dyskusja nad tą kwestią trwa do dzisiaj i wiąże się z kolejnym problemem, jakim jest integracja metodologiczna podejść geograficznych z nowymi koncepcjami w naukach społecznych, które z tych wielopłaszczyznowych podejść badawczych stosowanych w innych dyscyplinach naukowych najlepiej oddają geograficzny charakter badań i wspierają przestrzenne analizy zróżnicowania zjawisk (Bohle 2007).

W centrum geograficznym badań nad rozwojem znalazły się więc zagadnienia rozwoju i niedorozwoju, dysproporcji w poziomie zagospodarowania przestrzennego i w poziomie życia mieszkańców. Wyjaśnienie tych kwestii wymagało odwołania się do teoretycznych koncepcji wyjaśniających i ekstrapolowanych na grunt geografii. Najczęściej stosowano więc teorię modernizacji lub teorię zależności.

Geografia społeczno-ekonomiczna w latach 70. XX w. z entuzjazmem przyjęła i szeroko stosowała $\mathrm{w}$ procesie wyjaśniania przestrzennej struktury gospodarki teorię modernizacji (Scholz 2004). Już Behrendt (za: Bohle 2007) w latach 70. XX w. interpretował niedorozwój jako społeczne, gospodarcze i kulturalne zacofanie regionu lub miejsca w porównaniu z modernizującymi się obszarami kraju lub regionu. Za stan niedorozwoju obarczał czynniki wewnętrze, tkwiące w danej społeczności i tak silnie zakorzenione, że nie pozwalają temu społeczeństwu na otwarcie się na impulsy z zewnątrz oraz akceptację nowych idei i produktów (także technologii) (za: Bohle 2007). Tradycyjne stosunki społeczne oparte na konserwatywnych relacjach między poszczególnymi członkami danej społeczności, w tym dominująca rola zachowawczych, obawiających się utraty władzy elit politycznych i społecznych, które były zainteresowane utrzymaniem istniejącego status quo hamowały innowacje, a tym samym modernizację techniczną i społeczną. Takie kulturowo-polityczne uwarunkowania rozwoju sprzyjały utrzymywaniu się sytuacji zacofania i ubóstwa. Promowaniem strategii modernizacji krajów 
rozwijających się były zainteresowane kraje uprzemysłowione, które za dostarczenie pomocy technicznej i finansowej krajom Trzeciego Świata uzależniały ich gospodarkę od popytu na ich surowce i dalszą pomoc.

W teorii zależności niedorozwój przedstawiany jest w formie skrzywionego modelu społeczno-gospodarczego narzuconego przez kolonializm, a następnie imperializm, które narzuciły relacje wewnątrz określonych terytoriów prowadzące do deformacji struktur przestrzennych (Senghass 1974). Polityki kolonialne i postkolonialne stosowane przez państwa rozwinięte gospodarczo w krajach rozwijających się doprowadziły do powstania enklaw ze wszelkimi symbolami nowoczesności wewnątrz ich terytoriów (centrum) i rozległe obszary peryferii. Ta polaryzacja przestrzenna gospodarki i społeczeństwa okazała się być tak trwała, że przetrwała do dnia dzisiejszego i stanowi element nieodłączny relacji centrum-peryferia na poziomie terytorium narodowego.

Geograficzne badania nad rozwojem przyniosły wiele prac empirycznych zrealizowanych w różnych częściach globalnego Południa. Chociaż pojedyncze przypadki pokazują ogromne zróżnicowanie warunków, w jakich dochodzi do kształtowania się procesów rozwoju, jednak wynika z nich także to, że trudno jest wyjaśnić stan rozwoju i relacji integrujących globalne Południe z krajami rozwiniętymi gospodarczo stosując $\mathrm{w}$ analizie jedynie jedną z przedstawionych teorii (czy to teorię modernizacji czy też teorię zależności). Zawsze bowiem struktury przestrzenne gospodarki i ludności są zniekształcone przez polityki i strategie kolonialne oraz ich konsekwencje neokolonialne.

\section{Studia nad rozwojem i geografia rozwoju}

Geografia rozwoju jest stosunkowo młodą subdyscypliną geografii. Jej początki sięgają końca lat 60. XX w., od kiedy geografowie zainteresowali się problematyką rozwoju, niedorozwoju i zacofania krajów ówcześnie nazywanych Trzecim Światem. Ożywienie dyskusji na temat stanu i perspektyw geografii, które nastąpiło od początku lat 70 . XX w. przyczyniło się również do wypowiedzi na temat geografii rozwoju, szczególnie wśród reprezentantów geografii radykalnej (Grzeszczak 1981). W latach 70. XX w. badania krajów Afryki, Azji i Ameryki Łacińskiej realizowane były w ramach „studiów rozwojowych” (Grzeszczak 1981: 8), czyli także geograficzne badania tych regionów, jeśli nie były klasyfikowane jako geografia regionalna zaliczały się do wspomnianego nurtu badań. W 1977 roku D. Seers pisał o konieczności reorientacji studiów rozwojowych (Seers 1977), a głównym postulatem autora była konieczność rozszerzenia badań o wymiar przestrzenny. Miał na myśli głównie poszukiwanie relacji przestrzennych, które prowadzą do niedorozwoju lub utrzymują stan zacofania. Twierdził, że takie relacje występują nie tylko w krajach Trzeciego Świata, ale także w Europie (ibid.). W tym czasie studia nad rozwojem miały wyraźnie charakter wielodyscy- 
plinarny, chociaż geografowie również się do nich włączali. Lata 80. XX w. przyniosły specjalizację badań nad rozwojem w ramach poszczególnych dyscyplin. Najważniejsze kierunki badawcze w tamtym okresie wytyczane były przez antropologię, gdzie powstało wiele najważniejszych prac z zakresu lokalnych podstaw rozwoju w wybranych krajach rozwijających się. Ważny był wkład w dyskusję nad rozwojem i ubóstwem ekonomii, socjologii, politologii i wreszcie geografii.

Popularność geografii rozwoju sprawiła, że subdyscyplina ta zaczęła zastępować $\mathrm{w}$ dydaktyce akademickiej i w organizacji badań tradycyjną geografię regionalną. Jej przedmiotem badań stał się rozwój - proces budowania (tworzenia) i reorganizowania zasobów ekonomicznych w celu zwiększenia wydajności (Scott 2002: 138). Natomiast wzrost jest wyrazem tego działania i przejawia się wzrostem dochodu narodowego. Oba te procesy są niezwykle skomplikowane i krzyżują się ze sobą na różnych poziomach odniesienia w skali geograficznej i organizacyjnej (Scott 2002: 138). Każdy z poziomów geograficznego odniesienia - lokalny, regionalny, globalny jest zdolny do generowania silnego efektu synergii, mobilizując całą gamę czynników (aktorów), które dzięki wzajemnemu na siebie oddziaływaniu w konkretnej przestrzeni zwiększają szansę na rozwój danego miejsca. Zbiór czynników należących do podsystemów: kapitału i pracy (zróżnicowanych w zależności od typu, wieku, skuteczności, płci etc.) jest głównym sprawcą działania wewnątrz każdej jednostki produkcyjnej lub instytucji (niezależnie od jej wielkości). Ich stopień synergii zależy od cech technicznych, organizacji i zarządzania, cech kulturowych miejsca itp. (Scott 2002: 139). Pojedyncza firma (lub działalność gospodarcza) mogą tworzyć jedno przedsiębiorstwo lub wiele przedsiębiorstw połączonych w jedną sieć ze względu na własność i sposób zarządzania aż do powstania firm wielonarodowych (Scott 2002: 139). Przedsiębiorstwo wielobranżowe wytwarza dodatkowo relacje synergii. Przedsiębiorstwa grupują się w zależności od rodzaju działalności i tworzą szczególną strukturę organizacyjną lub instytucjonalną, generując zazwyczaj korzyści konkurencyjne. Dla badań geograficznych najważniejsze są kwestie lokalizacji firm oraz ich koncentracji w regionach. Wyższy poziom organizacji związany z aglomeracją firm stanowi szczególnie ważny wymiar rozwoju i wzrostu z silnym efektem pobudzania gospodarki. Tym samym więc, jak to często powtarzają autorzy zajmujący się zagadnieniami rozwoju, niektóre regiony posiadają silne atrybuty uruchamiające lub wzmacniające te procesy, a w innych ich brakuje.

Inny kierunek dyskusji nad rozwojem i niedorozwojem skupia się na roli ICT w stymulowaniu postępu, rozwoju gospodarczego i społecznego regionów marginalizowanych i zacofanych. Koncepcje i współcześnie głoszone poglądy w pracach naukowych dotyczące związków między rozwojem a ICT nieuchronnie opierają się na epistemologii geograficznej. Ogromne możliwości komunikacji jakie stworzył Internet sprawiły, że pojawiła się koncepcja cyberprzestrzeni, która jest wprawdzie metaforą przestrzeni przyjętej jednak w dyskursie 
naukowym ze względu na fakt, że tworzą ją sieci. Zmieniająca się cały czas natura cyberprzestrzeni sprawia geografom jednak trudności w osadzeniu swoich analiz odnoszących się do kreślonych, zdefiniowanych terytoriów. W cyberprzestrzeni trudno jest ustalić terytorialność relacji.

To rozróżnienie między przestrzenią i cyberprzestrzenią stworzyło podstawy dla opracowania nowych koncepcji i idei na temat rozwoju regionalnego (Graham 2008). Dla geografa rozwoju badanie tych atrybutów i relacji, które w szczególnych połączeniach i kombinacjach przyczyniają się do pobudzania efektów wzrostu i pozytywnych zmian w regionach stanowi najważniejsze pole analizy. W przypadku geografii rozwoju szeroki zakres badań dotyczy nie tylko dysproporcji w rozwoju, ale przede wszystkim regionalnymi wymiarami „rozwoju peryferyjnego" (Scott 2002: 138).

W swoich rozważaniach na temat przedmiotu badań i kierunków, w jakich ewoluuje tematyka badawcza geografii rozwoju H.-G. Bohle (2007) wyróżnia cztery wyraźne nurty, z których żaden nie stanowi dominującego pola badań geografii. Można je określić jako wielodyscyplinarne o silnym aspekcie przestrzennym (terytorialnym), gdzie geografia ma także swoje miejsce. Pierwszy z nich nazywa „ekonomicznym podejściem w geograficznych badaniach nad rozwojem” (Bohle 2007). Przez wiele lat rozwój utożsamiany był ze wzrostem gospodarczym, a geografowie idąc w ślady ekonomistów, opierali swoje analizy na badaniu stopnia przestrzennego zróżnicowania wskaźników pkb na 1 mieszkańca. Większość prac geograficznych, w tym również tych, które dotyczyły analiz rozwoju regionalnego wykorzystywała wspomniany wskaźnik. Rozpowszechnienie pkb na 1 mieszkańca jako głównego miernika poziomu rozwoju przez instytucje międzynarodowe, w tym ONZ sprawiło, że bezkrytycznie przyjmowano jego wartości na poziomie krajowym i mniejszy nacisk kładziono na analizy regionalne wewnątrz terytoriów poszczególnych państw. Dopiero studia z planowania i rozwoju regionalnego rozwijane pod auspicjami CEPAL-u i ILPES-u w Ameryce Łacińskiej pokazały niezwykle skomplikowaną strukturą społeczno-gospodarczo-przestrzenną krajów regionu, a ich autorzy wprowadzili koncepcję centrum-peryferii na poziom regionów wewnątrz państw (Boisier 2004; Dembicz 2008).

Drugim ważnym kierunkiem badań w geografii rozwoju, który także wykracza tematycznie daleko poza zakres badań stricte geograficznych są studia nad rolą instytucji i zarządzania w procesach regionalnych stymulujących rozwój. Analizy dotyczące nowej roli czynników i modeli zarządzających (governance) w rozwoju regionalnym (Lackowska 2009), procesów decentralizacji - coraz silniejszych także w krajach globalnego Południa, wzrostu roli organizacji pozarządowych $\mathrm{w}$ walce $\mathrm{z}$ ubóstwem i zacofaniem regionów, rosnąca rola społeczeństwa obywatelskiego w procesach przemian regionalnych - to tylko niektóre z tematów, które podejmuje geografia rozwoju. Obok nich pojawiają się inne, związane z różnymi sektorami gospodarki. Geografia rozwoju zajmuje się m.in. analizą regulacji 
instytucjonalnych w sferach, gdzie najczęściej pojawiają się konflikty, m.in. konflikty o ziemię (Coy 2001; Neuburger 2001), konflikty o dostęp do wody (Büttner 2001), o zachowanie pokrywy leśnej (Czerny, Czerny 2016). Działalność instytucji bada się pod kątem ich skuteczności i niezależności od polityki i presji ze strony różnych grup interesów (w tym międzynarodowych firm eksploatujących zasoby). Powinny one stanowić gwarancję dla zrównoważonego gospodarowania zasobami (Bohle 2007). Krytycy tego kierunku badań w geografii rozwoju zarzucają autorom, że instytucje w krajach globalnego Południa traktuje się jako autonomicznie funkcjonujące, bezstronne, niezależne od kontekstu politycznego i kulturowego organizmy zainteresowane wspieraniem procesów rozwoju. Tymczasem, jak to wynika z licznych analiz przeprowadzonych m.in. przez autorkę tego opracowania, instytucje lokalne są silnie upolitycznione i stanowią symbol klientelizmu i walki grup interesów o zarządzanie zasobami na najniższym poziomie podziału administracyjnego.

Badania kwestii społecznych w geografii rozwoju skupiły się na analizie ról różnych aktorów $\mathrm{w}$ procesie rozwoju, szczególnie w procesie podejmowania decyzji zarówno przez czynniki instytucjonalne, jak i indywidualne osoby czy rodziny wobec wyzwań wychodzenia z sytuacji zagrożeń, kryzysów i katastrof (Czerny 2012). Liczne studia przypadku zrealizowane w wielu regionach świata pokazują bardzo duże różnice dotyczące modeli i sposobów wychodzenia z ubóstwa, niedorozwoju i kryzysu. Także proces podejmowania decyzji i ich motywacje odnośnie preferencji rozwojowych są bardzo zróżnicowane w zależności od kraju i regionu. Dla społeczeństw zamieszkujących regiony peryferyjne, często nawiedzane przez klęski żywiołowe, kryzysy lub wojny, zabezpieczenie takich podstawowych aktywów, umożliwiających nie tylko poprawę sytuacji życiowej, ale często przetrwanie jak: ziemia, kapitał, umiejętności i wykształcenie, zdrowie, dobre sąsiedztwo i więzy wspólnotowe są kluczowe dla zagwarantowania podstaw dalszej egzystencji. Paletę aktywów i rolę każdego z nich w rozwoju bada również geografia rozwoju (Czerny, Córdova-Aguilar 2014; Serna Mendoza, Czerny i in. 2015).

\section{LITERATURA}

Andreasson S., 2005, Orientalism and African Development Studies: the 'reductive repetition' motif in theories of African underdevelopment, „Third World Quarterly”, 26(6), s. 971-986.

Bohle H.-G., 2007, Geographische Entwicklungsforschung. Kapitel 24, [w:] Gebhardt H., Glaser R., Radtke U., Reuber P. (red.), Geographie. Physische Geographie und Humangeographie, Spektrum Akademischer Verlag, Heilderberg.

Boisier S., 2004, Desarrollo territorial y descentralización. El desarrollo en el lugar y en las manos de la gente, „Revista EURE”, 30 (90), Santiago de Chile, s. 27-40. 
Büttner H., 2001, Wassermanagement und Ressourcenkonflikte. Eine empirische Untersuchung zu Wasserkrise und Water Harvesting in Indien aus der Perspektive sozialwissenschaftlicher Umweltforschung, Freiburger Studien zur Geographischen Entwicklungsforschung 19, Verlag für Entwicklungspolitik, Saarbrücken.

Coy M., 2001, Institutionelle Regelungen im Konflikt um Land-zum Stand der Diskussion, „Geographica Helvetica”, 56(1), s. 56-57.

Czerny M., 2012 (red.), Bieda i bogactwo we współczesnym świecie. Studia z geografii rozwoju, WUW, Warszawa.

Czerny M., Córdova-Aguilar H., 2014, Livelihood - Hope and Conditions of a new Paradigm for Development Studies. The Case of Andean Regions, NOVA, New York.

Czerny M., Czerny A., 2016, Bogota - urban expansion. Social segregation and land degradation, Papers on Global Change, IGBP PAN.

Dembicz K., 2008, CEPAL i latynoamerykańska myśl regionalna, Uniwersytet Warszawski, CESLA.

Graham M., 2008, Warped Geographies of Development: The Internet and Theories of Economic Development, „Geography Compass”, 2/3, s. 771-789.

Grzeszczak J., 1981, W kierunku geografii rozwoju, PZLG - Problemy geografii rozwoju, 4, s. 5-14.

Hausmann R., 2001, 'Prisoners of Geography', Foreign Policy, January, s. 44-56.

Lackowska M., 2009, Zarządzanie obszarami metropolitarnymi w Polsce. Między dobrowolnościq a imperatywem, WUW, Warszawa.

Landes D., 1999, The Wealth and Poverty of Nations: Why some are so rich and some so poor, WW Norton, London.

Mohan G., Power M., 2009, Africa, China and the 'new' economic geography of development, „Singapore Journal of Tropical Geography”, 30(1), s. 24-28.

Neuburger M., 2001, Landrechte in Brasilien - zur Bedeutung institutioneller Regelungen für Verwundbarkeitund Überlebensstrategien kleinbäuerlicher Gruppen, ,Geographica Helvetica", 56(1), s. 34-47.

Sachs J., 2006, The End of Poverty: Economic Possibilities for Our Time, Penguin, London.

Scholz F., 2004, Geographische Entwicklungsforschung. Methoden und Theorien, Gebrüder Borntraeger Verlagsbuchhandlung, Berlin-Stuttgart.

Scott A., 2002, Regional push: towards a geography of development and growth in low and middle-income countries, ,Third World Quarterly”, 23 (1), s. 137-161.

Seers D., 1977, Back to the Ivory Tower? The Professionalisation of Development Studies and their extension to Europe, ,IDS Bulletin”, 9(2), s. 6-11.

Senghass D. (red.), 1974, Peripherer Kapitalismus. Analysen über Abhängigkeit und Unterentwicklung, Suhrkamp Verlag, Frankfurt/Main.

Serna Mendoza C.A., Czerny M., Londoño Pineda A.A., Velez Rojas O.A., 2015, Livelihood assessment in the district 1 of Medellin - Colombia, „Miscellanea Geographica - Regional Studies on Development", 19(4).

Watts M., 2003, Development and Governmentality, „Singapore Journal of Tropical Geography", 24(1), s. 6-34. 


\section{GEOGRAPHICAL RESEARCH FACING CHALLENGES OF INTERDISCIPLINARITY OF STUDIES ON DEVELOPMENT}

Abstract Geographical studies on the development represent a proposal for a integration of some of research topics undertaken by both physical and human geography. Their aim is to analyze the social and economic processes through the prism of natural conditions and their position in particular spaces. Such an assumption makes that the main object of the researchers are the relationships and spatial phenomena of development and underdevelopment.

The concept of geography of development was introduced to geography by Jürgen Blenck in 1979. In the center of the geographical studies on development Blenck puts society that occupying a defined space of the specific conditions of the natural environment are creating a network of relations that will either lead to the development or inhibit this process. Blenck postulated the concentration of geography of development on the investigation of processes of development and underdevelopment of specific pieces of geographical space and not strictly on developing countries, as it has been done previously. Thus, there has been a change of paradigm of geographical research from purely spatial analyzes of differences of phenomena and processes to the sociocultural causes of underdevelopment and differentiation of living standards. Geography began to use to explain the spatial aspects of the development the theories and concepts borrowed from the social sciences and economics. It emerged the need for interdisciplinary research on development directed to the micro-regional analysis. At the same time incorporating of geography into the debate about globalization - its conditions and environmental, social, economic, cultural and political effects gave impetus to the discussion on the broader spatial level, on the sclae of large geographic regions and globally.

Keywords Geography of developing countries, geography of development, development studies, global South.

Prof. dr hab. Mirosława Czerny Zakład Geografii Rozwoju i Planowania Przestrzennego Wydział Geografii i Studiów Regionalnych Uniwersytet Warszawski e-mail: mczerny@uw.edu.pl 